\title{
Social and Economic Foundations of Community Education for Peace in Islam
}

\author{
TAIWO T. AMBALI ${ }^{1}$
}

\begin{abstract}
This article highlights and discusses propositions in hadith and the Holy Quran could form social and economic bases of adult community education curriculum designed for the promotion of peace in Nigeria and the world. The paper is evoked by three interrelated reasons. First, in recent times violence appears to be springing up and spreading intractably in the world and especially in Nigeria which begs for sustainable solution. Second, while Islam is a religion of peace, there is wide misconception pointing to the contrary with the act of violence seemingly prevalent in Muslim dominated areas or perhaps being perpetuated by not well informed Muslims. Third, architects of violence in most instances are both educated and uneducated who may need to de-learn and re-learn Islamic position on promotion of peace through adult community education. Following the discussion, the paper draws implications for the development of relevant peace education curriculum and mode of delivery.
\end{abstract}

Keywords: community education, Islam in Nigeria, religion and peace

Intra-national and global peace is of a serious concern to everyone living in developed or developing countries. Fajonyomi (2015) emphasised that the issue of peace is of immense importance and of unquestionable urgency in the world of today. Looking round the globe there is no continent spared of intra-national or cross border armed struggle, insurgency, terrorism, violence, war, or action which is antithesis of peace. However, for Al-Shabab and Boko-Haram attacks in Africa, more than 25 years of violence and armed struggle in the province of Aceh, Indonesia and activities of ultra-violent Muslims in Sri-Lanka, Bangladesh, and Philippines in Asia or inter-continental rabid warfare of ISIS, al-Qaida and other similar radical groups in Syria, Europe and United States of America, there are insinuations to wrongly attribute violence to Islam and Muslims in general.

Conversely, if over 1.8 million Muslims of the world's population were to be violent prone, perhaps the entire world would have been on 'fire' and unbearable to live in. In other words, the act of violence is pockets of Islamic fundamentalists who are heedless to the principles of Islam and the teachings of the Prophet in the Quran and Hadith on peace and peaceful co-existence among fellow Muslims and between Muslims and Non Muslims within a community be it a neighbourhood, state, nation or the globe. That is, members of such radical groups should be made to de-learn the radical and misconceived knowledge of how to pursue or seek justice and peace based on Islam. And to the contrary, they would re-learn the true position. Non-members of the groups, especially the vulnerable in the community, must be educated on the 'true' teachings of Islam on peace, harmony and justice. Even the deradicalization initiative of 'repented' members of these groups conceived by some national governments, including Nigerian Government, cannot be successful outside education or better community education for peace and for short peace education. One of the advantages of

\footnotetext{
${ }^{1}$ Taiwo T. Ambali, Ph.D., lecturer at Department of Adult \& Primary Education, Faculty of Education, University of Ilorin, Nigeria, email: taiwotoyinambali@gmail.com.
} 
education for peace is the opportunity provided to clarify some statements in the which are often misunderstood and misappropriated (Tanenbaum Center for Interreligious Understanding 2014: 2 \&14)

Importance of peace as the bedrock of personal and societal development is underscored by its definition and the various initiatives on it. For instance, Akanji and Oyitso (2011) consider peace as a corner stone or the pillar that supports a harmonious existence of a family, community or a country. It also encompasses the presence of social, economic and political justice which is essential to the notion of 'positive peace' (Hicks 1985 in Fountain 1999: 1). A mark of negative peace is 'structural violence' is a term that is used to refer to injustices such as poverty, discrimination and unequal access to opportunities, which are at the root of much conflict. Structural violence is perhaps the most basic obstacle to peace, which by definition cannot exist in a society in which fundamental human rights are violated. Very recently and perhaps in realization of the fact that no sustainable development can occur without peace and security, goal 16 of the Sustainable Development Goals (SDGs) underscore the importance of peace and security: Promote peaceful and inclusive societies for sustainable development, provide access to justice for all and build effective, accountable and inclusive institutions at all levels (Derek, Amy \& Farooq 2015: 4).

For emphasis, the need for peace cannot be over flogged, especially for the social and economic cost of violence in whichever form. That is the cost of the violence as a result of the attacks is just unimaginable. Therefore, every effort to ensure that peace reigns in the world community should be welcome. This is the crux of this paper. Precisely, Islamic perspectives on economic and social issues which often form bases for conflicts, violence and war are highlighted and summarily discussed. In addition, modus operandi of passing such information and knowledge from one generation to another in form of educational curriculum is suggested. Since a community as noted by Habibullah (1992: 49) 'may not be based squarely on Islamic principles and there may possible deviations from Islam' this paper concludes with a proviso that the 'realities' of a community should be factored into discussion as part of the social and economic foundations.

\section{Community Education for Peace in Islam (CEfPiIs)}

Community Education (CE) is entrenched in the realm of childhood, youth and adult education. It addresses concerns of members of a community, be it a village, town, nation or larger as long as members have common economic, political and social interests. Being educational programme, CE transmits knowledge, skills and values from one generation to the other. For this reason, age long definition given by Liveright \& Haygood in Egenti (2012: 21) is still relevant. The authors defined CE as:

Process whereby persons who no longer attend school on a regular or full-time basis undertake sequential and organised activity with conscious intention of bringing about changes in information, knowledge, understanding or skill, appreciation and attitudes or for the Purpose of identifying and solving personal or community problems.

As members of a community are of different ages CE is not age bound even though deepness of the content and approaches to be adopted would differ. It suggests that resources, ranging from human to non-human resources reside in the community. According to Aujara (2011: 60 \& 61) CE is characterised by these two features among others: involvement of all community members and resources in the planning, organisation, and management of the education process and in teaching and learning and recognition of CE as a system with various 
educational agencies and institutions playing complimentary roles and with proper coordination for good result.

Given that CE is a 'democratic process of education aimed at inculcating the right type of values, knowledge and skills for community problem solving and actualisation of individual and ideals' is to conceive community education for peace in Islam (CEfPiIs) as addressing spate of violence perpetuated by heedless Muslims with misapprehension of what Islam stands for in guaranteeing peace of the individual and that of the community as provided in the Qur'an and Hadith. It is not out of place to indicate that CEfPiIs has the spirit of lifelong education (LLE) in which education is diffused throughout society, taking place in formal, non-formal and informal settings and cutting across ages from cradle to grave and promoting equality, justice, harmony, cultural and social integration, and entrepreneurship (Boshier 2006: 24-30 \& Fajonyomi 2008: 7-9). See figure 1.

The ultimate goal is to evoke and sustain peace in the community lived in by Muslims and non-Muslims, even in communities where Muslims constitute the majority. Hence, CEfPiIs has the letter of peace education, a 'process of promoting the knowledge, skills, attitudes and values needed to bring about behaviour changes that will enable children, youth and adults to prevent conflict and violence, both overt and structural; to resolve conflict peacefully; and to create the conditions conducive to peace, whether at an intrapersonal, interpersonal, intergroup, national or international level' (Fountain 1999: 1).

'The Future Global Agenda for Children - Imperatives for the Twenty-First Century' (UNICEF 1999, E/ICEF/1999/10) makes a commitment to ". . . ensure that education and learning processes help to form both human capital for economic growth and social capital for tolerance, respect for others and the right of each individual to participate with equality within family, community and economic life; ... and to challenge the culture of violence that threatens to destroy family and community life in so many countries."

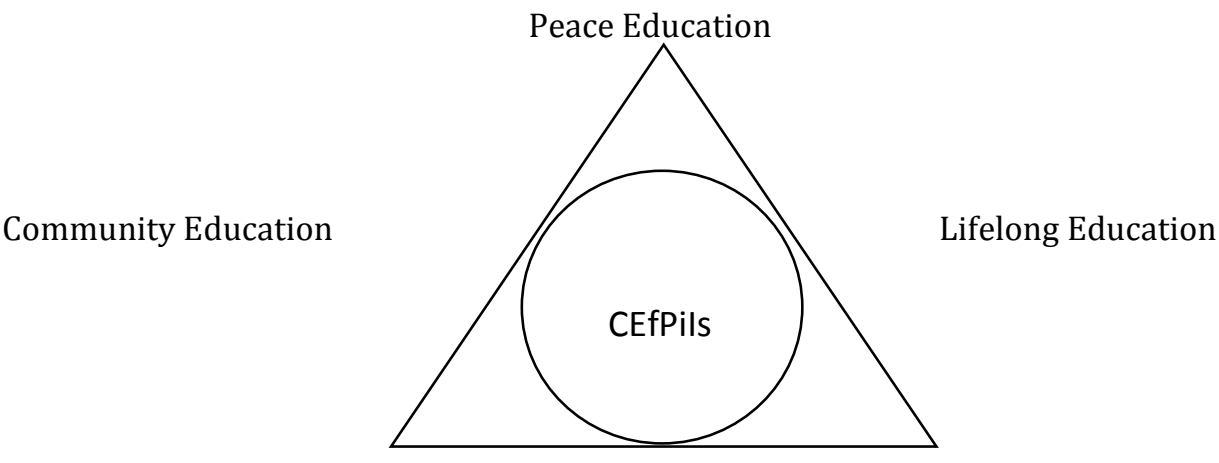

Fig. 1: CEfPils as interception among Community Education, Lifelong Education and Peace Education

A cursory look at similar programme in Aceh, Indonesia is very informing (Wells 2012). The programme has six principles which form the foundation for the curriculum include: introspection and sincerity; rights and responsibilities; conflict and violence, democracy and justice; plurality of creation; and paths to peace. Each of which is padded with Acehnesse proverbs that have superficial as well as deeper meaning for bringing about peace and justice:

In addition, central to the curriculum is the teaching that Allah desires peace. It is not enough to have peace just between the individual and Allah, however. If there is injustice or inequality among humans, then Allah is not satisfied. Moreover, Islam teaches that peace is not a receptive, passive condition where only self-interests are served. Rather peace is a dynamic which must be continually refined, redefined and struggled to achieve. In achieving peace, humans must examine our wants and needs. We all experience social, spiritual, 
physical and psychological needs, all of which must be kept in a rough balance to maintain peace. Our excessive wants, however, are often the cause of conflict and violence because this means that others needs are not being met. The peace paradigm this curriculum espouses is one where Allah encompasses the realms of peace within, peace in the community, and peace with nature. The Aceh peace education curriculum teaches that in Islam, nature is meant to serve our needs not our wants. Therefore, to have peace with Allah and peace between human beings, we must also respect the peace that exists in nature and not take advantage of natural resources which bring great wealth to a few and great poverty to many. It is the economic injustices that are perpetrated at a structural level which cause tremendous personal violence on an individual level (Wells 2012: 1).

The peace education programme appears to be summed up in the purpose of peace education within the Muslim world given by Koylu (2008: 4) as 'to cultivate the consciousness of students regarding social, economic and political problems facing the Muslim community, informed understandings of Islamic jihad, religious freedom and tolerance, productive relationships with non-Muslims internationally, and individual and social responsibility based on the Qur'an and authentic Traditions of the Prophet Muhammad. This purpose equally fits the purpose of CEfpils.

The description of CEfPiIs leads to isolation of six strategic operational areas which are presented in figure 2 and discussed in the next section as the package for the 'Social and Economic Foundations of Community Education for Peace in Islam'

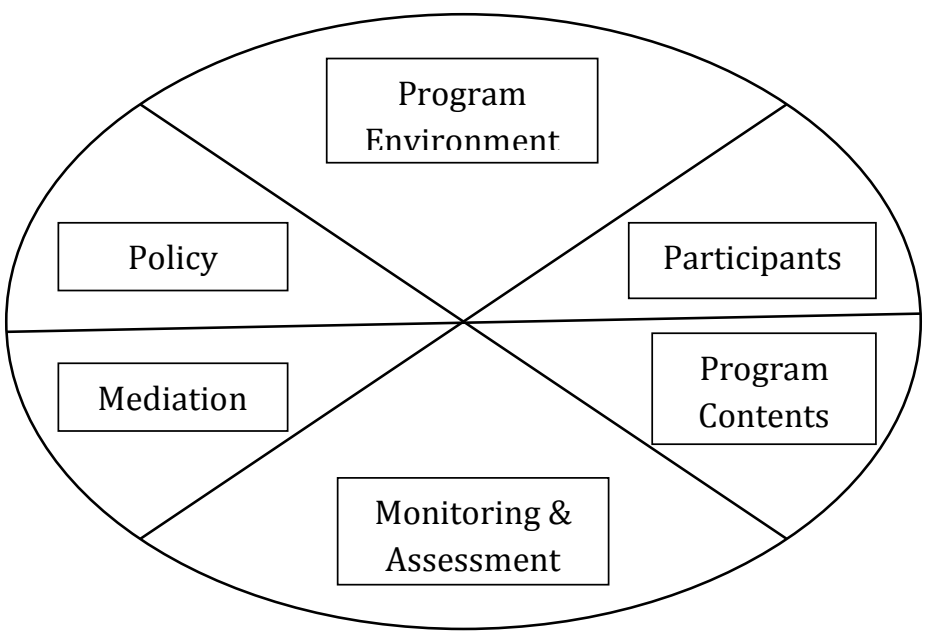

Figure 2; Six dimensions of the CEfPiIs.

\section{Policy Statement}

Policy, likened government's interest, provides foundation for programme development and if poorly laid signals weak, ineffective and inefficient programming well as leads to failure of the programme from the outset (Fajonyomi 2015). It then becomes imperative to provide policy guide containing strategies for effective and enduring of performance of the programme as this. The policy should be specific on estimated cost of the programme and how it will be funded including resourcing in terms of human and materials; scale of the programme in terms of range of educational needs, the numbers of people to involved as well as their distribution in space and time; relevance with a link to social, political and economic objectives; flexibility, finding 
ways to build both structural and process flexibility; and mode of monitoring and assessment for the programme's future and sustainability (Morrison 1995: 195-197).

\section{Programme Environment}

The programme environment is highly amorphous, in cyber space and physical learning environment-informal, formal and non-formal. Family and other social institutions, including schools, are not excluded.

\section{Programme Content}

Societal Ethos: Laws and policies of the land on responsibilities, duties, conduct of the members of the community; social values, norms and traditions of the society as related to peace and tenets of peace.

\section{Position of Islam on Peace:}

i. Islam religion preaches peace as every other religion does and guiding people to the right path. As al-Quran (2:256) quoted that, "there is no compulsion in religion".

ii. Peace is an integral part of Islam, reflected in the common greetings 'al-Salam alaikum and wa 'alaikum al-Salam', meaning peace be upon you and peace be upon you too (Koylu 2008: 1).

iii. Unity of the Human Race: According to the Quran, 'all men belong to one race and all men have been created out of Adam and all men have been asked to hold fast to the string of Allah and not to create dissension among themselves'. One of the traditions of the Prophet says "All created beings are the wards of Allah and whosoever loves His creation, He loves him" (Habibullah 1992: 51).

iv. Justice: "Allah commands that you should render back the trusts to whom they are due; and that when you judge between men, you judge with justice" al-Quran (4:58).

v. Equity: "O you who believe! Stand out firmly for Allah as just witness; and let not the enmity and hatred of others make you avoid justice" (al-Quran 5:8).

vi. Love: "Help you one another in virtue and righteousness but do not help one another in sin and transgression. And fear Allah. Verily, Allah is severe in punishment". (al-Quran 5: 2).

vii. Economic peace: "And He has made me blessed wheresoever I be, and has enjoyed on me Salat and Zakat, as long as I live" (al-Quran 19:31).

viii. Respect for the Humanity: 'The Quran proclaims that Allah has elevated the status and dignity of all sons of Adam. It is for them to make use of this status and not to delve down ignorance and evil and degrade himself' (Habibullah 1992: 53).

ix. Exegesis on concepts such as 'jihad' which are often misapplied emanating from misunderstanding.

x. Skill training and entrepreneurship education. Through this the participants would develop entrepreneurial skill and be occupied with work and not idle for them to be the devil's workshops.

\section{Participants}

The participants cut through ages as there is no age consideration in the recruitment into radicalism and the present membership of such groups include children, youths and adults. That is the target participants are radical and non radical Muslims and perhaps non Muslims who are likely to be sympathetic to extremism. It is even better to start the training at a tender age for 
those are yet to be recruited for them to be able to resist being cajoled. A Yoruba (Nigeria) proverb lends support to this, it says 'ati kekere lati pa eka iroko to ba dagba tan a ma soro' meaning it is easier to tender an iroko tree than when it is young than when it is old and big.

\section{Mediation}

Principally, the mediation has to be creative and innovative engaging various resources in the community-parents, religious leaders of all faiths, politicians and educational administrators and media personnel as well as the deployment of diverse instructional and educational media such as print, radio, television, computer and internet with the various social media applications. It is not news that insurgents and extremists listen and monitor information on radio, television and even satellite. Hence, these means should be used to pass on deradicalising messages which may have impact on active and passive radicals. Approaches may also include role modelling as models are visible letters being read; interactive discussion along what Paulo Freire (1970) referred to as conscientisation and focus group discussion. During discussion, participants are given opportunity to freely express their feelings on any issue related to peace. In all, mediation suggests flexibility and creativity. For instance, instead of using jets to bomb radicals in the field they can be used to distribute leaflets on selfinstructional messages on peace entrenched in Islamic principles.

\section{Monitoring and Assessment}

Monitoring and assessment may not be formal perhaps based on interview, self reporting and observation which should be done periodically. Assessment report should capture the views of the participants and programme providers. More importantly, community based coordinating unit should be established for this purpose.

To conclude, education is an instrument for social, economic, political and technological development. It is also an indispensable tool in peace building. With the close association between education and peace, it is suggestive that the spate of violence linked with Islamic radicalism could be stemmed by factoring community-focused peace education informed by the Quran and Hadith into peace building equation. Therefore, this paper proposed CEfPils package for trial as a contribution to ensuring enduring peace in every community as well as to seeing that every Muslim works towards peace of their community. However, the proposal would have to fine tuned to fit to emerging conditions of each community.

\section{References}

Al-Quran.

Akanji \& Oyitso. 2011. Community Empowerment as a strategy for sustainable peacea in the Niger Delta Region. Journal of the Institution of Education. 6(1 \& 2): 176-185.

Aujara, I. W. 2011. Community education and Nigeria education system. In, Ayodele Fajonyomi (ed.) Adult Education and Extension Services: Readings and Cases in Memory of Professor Y.Y. Dibal. pp. 57-74. Maiduguri: University of Maiduguri.

Boshier, R.W. 2006. Widening access by bridging education home. In, A. Oduaran \& H.S. Bhola (eds.) Widening Access to Education as Social Justice: Essays in Honour of Micheal Omolewa. pp. 23-43. Netherlands: Springer.

Derek, O; Amy, C. \& Farooq, U. 2015. Universal Sustainable Development Goal's: Understanding the Transformation Challenge for Developed Countries Report of a Study by Stakeholder Forum. Retrieved from http://www.stakeholderforum.org [Accessed 18 July 2016].

Egenti, M. N. 2012. Essential Foundations in Adult and Non-Formal Education. Lagos: Goshen Printmedia. 
Fajonyomi, A. 2008. Access, equity, and quality of education: a discovery response. In, I.A. Njodi, A. A. Fajoyomi, \& K. Bulama (eds.). Equity, Quality and Access to Education in Nigeria: Problems and the Way Forward. pp. 3-23. Maiduguri: University of Maiduguri.

Fajonyomi, A. 2015a. Experiential learning, adult education and community development for justice and peace: empowering harmony in Nigeria; adult education in Nigeria. Journal of Nigerian National Council for Adult Education. 20(1): 1-7.

Fajonyomi, A. 2015b. Policy and situational analysis of adult education in Nigeria: working towards lateral and vertical harmonisation of programmes. A paper presented at a Workshop organised by Commission for Mass Literacy, Adult and Non-formal Education, 8-11 December.

Freire, Paulo. 1970. Pedagogy of the oppressed. New York: Herder and Herder.

Habibullah, M. 1992. Social foundation of education in Islam. Bulletin of Education and Research. 1(1): $48-54$.

Islamic Research Academy. 2009. Al-Qur'an Kareem. Cairo: University of Azhar.

Koylu, M. 2008. Islam and peace education. Encyclopedia of Peace Education. Teachers' College, Columbia University http://www.columbia.edu/centers/ [Retrieved 01 August 2016].

Morrison, T. R. 1995. Global transformation and search for a new educational design. International Journal of Lifelong Education. 14(1): 188-214.

Muhammed, T. A. \& Muhammed, M. K. 2010. Translation of the Meanings of the Noble Qur'an in the English Language. Madinah: King Fahd Printing Press.

Fountain, Susan. 1999. Peace Education in UNICEF. New York: UNICEF

Tanenbaum Center for Interreligious Understanding. 2014. Islamic Peace Education: A Conversation on Promising Practices. New York: Tanenbaum.

Wells, Leah. 2012. Islamic Peace Education in Acheh. n.l. Nuclear Age Peace Foundation. 